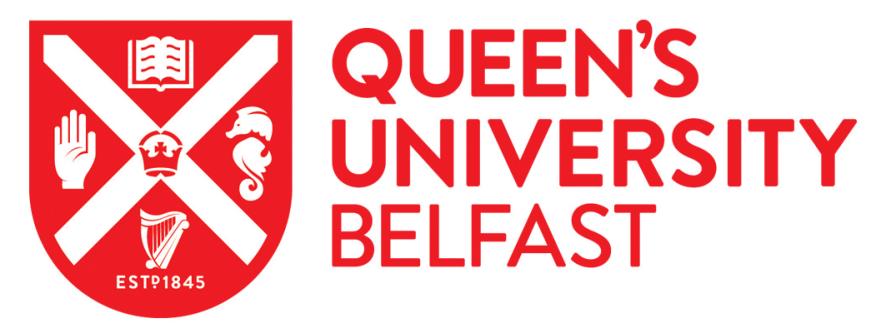

\title{
An international e-Delphi study to identify core competencies for Italian cardiac nurses
}

Bagnasco, A., Barisone, M., Aleo, G., Watson, R., Catania, G., Zanini, M., Thompson , D. R., \& Sasso, L. (2021). An international e-Delphi study to identify core competencies for Italian cardiac nurses. European Journal of Cardiovascular Nursing, 20(7), 684-691. https://doi.org/10.1093/eurjcn/zvab003

\section{Published in:}

European Journal of Cardiovascular Nursing

\section{Document Version:}

Peer reviewed version

Queen's University Belfast - Research Portal:

Link to publication record in Queen's University Belfast Research Portal

Publisher rights

Published on behalf of the European Society of Cardiology. All rights reserved. Copyright The Author(s) 2021.

\section{General rights}

Copyright for the publications made accessible via the Queen's University Belfast Research Portal is retained by the author(s) and / or other copyright owners and it is a condition of accessing these publications that users recognise and abide by the legal requirements associated with these rights.

Take down policy

The Research Portal is Queen's institutional repository that provides access to Queen's research output. Every effort has been made to ensure that content in the Research Portal does not infringe any person's rights, or applicable UK laws. If you discover content in the Research Portal that you believe breaches copyright or violates any law, please contact openaccess@qub.ac.uk. 


\section{Authors:}

\section{Annamaria BAGNASCO,}

Department of Health Sciences, University of Genoa,

Genoa, Italy

\section{Michela BARISONE,}

Interventional Cardiology Unit,

S. Corona Hospital

Pietra Ligure, Italy

\section{Giuseppe ALEO,}

Department of Health Sciences,

University of Genoa,

Genoa, Italy

\section{Roger WATSON,}

Faculty of Health and Social Care,

University of Hull,

Hull, UK

\section{Gianluca CATANIA,}

Department of Health Sciences,

University of Genoa,

Genoa, Italy

\section{Milko ZANINI,}

Department of Health Sciences Department, University of Genoa,

Genoa, Italy

\section{David R Thompson}

School of Nursing and Midwifery,

Queen's University Belfast,

Belfast, UK

\section{Loredana SASSO,}

Department of Health Sciences,

University of Genoa,

Genoa, Italy

\section{Corresponding author:}

Gianluca CATANIA, PhD, MSN, RN

Assistant Professor

Department of Health Sciences Department

University of Genoa,

Via Pastore, 1

16132 Genoa, Italy 
Email: gianluca.catania@edu.unige.it

\begin{abstract}
Background

The management of cardiovascular patients requires increasingly competent nursing professionals. In Italy, there are no specific postgraduate courses focused on specialist cardiac skills development for nurses. To develop such courses, content incorporating appropriate competencies is required and this study was designed to meet this.
\end{abstract}

\begin{abstract}
Aims
To delineate a set of core competencies to develop national educational interventions to ensure cardiac nurses in Italy achieve international standards.
\end{abstract}

\title{
Methods
}

A three-round e-Delphi study including a panel of 32 expert cardiac nurses from the UK, Canada, Australia, New Zealand and Italy was conducted; 26 respondents completed all three rounds. The first round sought a list of five competencies from each participant which they were asked to prioritise in round 2 . In round 3 they were asked to prioritise again with the knowledge of the priorities identified in round 2 . The final list of competencies was those achieving $70 \%$ agreement among participants.

\section{Results}

We identified 14 core competencies spanning a range of areas of competence including technical, interpersonal, health promotion, use of evidence and management. Only minor differences were evident between the Italian and the international panel regarding the priority given to some core competences, such a leadership and taking patient history. 


\section{Conclusion}

This is the first study in Italy to delineate cardiac nurses' core competencies. As such, it provides a foundation for the development of postgraduate educational programmes for cardiac nurses including competencies that are congruent with international standards.

\section{Keywords}

Delphi, core competence; cardiovascular nurses; postgraduate education

\section{INTRODUCTION}

Due to rapid advances in science, technology, medicine and nursing, cardiac nurses need to update, redefine and align their practice and education with the best available international evidence and standards. This is necessary to ensure optimal care for the increasing number of people affected by cardiovascular disease, many of whom are often admitted and readmitted to hospital, but also increasingly, especially in the case of heart failure, cared for in the community.[1] Nurses play a central role in the education and support of patients and families with cardiovascular diseases.[2]

Considering the impact that cardiovascular diseases have on the population, especially, and today's technological innovations and scientific progress, international scientific associations have published position statements that define the core curriculum for cardiac nurses, setting standards of reference that also enable nurses to self-assess their own competence.[3] By 'competence' we mean 'the habitual and judicious use of communication, knowledge, technical skills, clinical reasoning, emotions, values, and reflection in daily practice for the benefit of the individuals and community being served'.[4] The term competence was first applied to other skills-based occupations and then adopted by nursing.[5] The term 'competency' (plural 'competencies'), which is the focus of this study, refers to the specific components of competence. 
To provide a detailed list of the competencies that cardiac nurses should meet, the principal European Society of Cardiology (ESC) associations, such as the Heart Failure Association (HFA) and the European Association of Percutaneous Cardiovascular Interventions (EAPCI), have drafted position statements principally to define standard competencies under the form of a core curriculum. The ESC Association of Cardiovascular Nursing and Allied Professions (ACNAP) has produced various position statements with a list of specific competencies and healthcare standards required to care for patients affected by cardiovascular diseases.[6] A large study conducted in nine European countries showed how care provided by nurses with higher levels of education significantly reduces the risk of mortality.[7] The purpose of a core curriculum for the management of cardiovascular diseases is to provide a framework for all the countries that are part of the Education Committee of the former Council (now Association) of Cardiovascular Nursing and Allied Professions (CCNAP), to enable cardiac nurses to work and collaborate in a fully integrated manner with other health professionals through an evidence-based approach.[8] In 2016, the Education working group of the nurse and allied professions committee of the European Association of Percutaneous Cardiovascular Interventions (EAPCI), through Benner's 'stages of clinical competence',[9] identified and listed the competencies that cardiac catheterisation laboratory nurses should have to manage specific clinical conditions, such as coronary artery disease, heart rate management, and structural heart disease. The common denominator of these position statements is the definition of the cardiac nurses' scopes of practice, which not only includes aspects related to clinical practice (e.g. reading and interpreting an ECG, monitoring vital signs, etc.), but also specific aspects of the nursing profession, such as non-technical skills, especially communication and relational skills.[8]

The development of guidelines (e.g. ESC guidelines for the diagnosis and treatment of acute and chronic heart failure) highlights the importance of the nurse's role in the effective management of cardiovascular diseases.[10] However, the roles and responsibilities of cardiac nurses vary greatly across Europe, due to the geographical influence of their workplace, their educational 
preparation and the professional regulations of their country.[11] In Italy, for instance, unlike many other European countries, there are no postgraduate academic courses on specialised advanced competencies for cardiac nurses. In fact, Italian cardiac nurses gain their advanced competencies directly in the field, through their clinical experience.[12] Therefore, in this study we aimed to identify a set of internationally accepted core cardiac nursing competencies that would serve as the basis for specialist postgraduate courses, for cardiac nurses in Italy.

\section{Aim}

To identify a set of core competencies for cardiac nurses in Italy that meet international standards for postgraduate specialization courses.

\section{METHODS}

\section{The Delphi survey}

The Delphi technique is a widely used and accepted method for achieving convergence of opinion concerning real-world knowledge solicited from experts in certain topic areas.[13] Described by Dalkey and Helmer[14] as a method to obtain the most reliable consensus of a group of experts by a series of intensive questionnaires interspersed with controlled feedback, the main premise of the Delphi method is the assumption that group opinion is more valid than individual opinion. While the participants do not interact directly with one another in the process of a Delphi study, consensus is achieved because participants can change their opinion as a result of seeing the combined responses of the other participants. As described by the 'Better Evaluation' website,[15] the Delphi technique is a quantitative method aimed at generating consensus. It solicits opinions from groups in an iterative process of answering questions. The Delphi technique works using a multi-staged survey.[16] After each round the responses are summarised and redistributed for consideration in the next round. Through a process of convergence involving the identification of common trends and inspection of outliers, a consensus is reached. The Delphi method has been frequently and effectively used in healthcare to obtain consensus around priorities for education, research and 
service delivery [17-20] and is entirely suitable for the present project.

In each round of a Delphi survey, a summary of the results of the previous round is included and evaluated by the panel members. McKenna implies that this process facilitates the 'systematic emergence of a concurrence of judgement/opinion' (p. 1222).[16] The number of rounds depends on the time available and whether the study started the Delphi sequence (Round 1) with one broad question or with a list of questions or events. The process raises the question of how many rounds it takes to reach consensus. The classical original Delphi used four rounds. However, this has been modified by many to suit individual research aims and, in some cases, it has been shortened to two or three rounds. It is difficult to retain a high response rate in a Delphi survey that has many rounds; the topic needs to be of special interest to the panel members.

The advantages of the e-Delphi are obvious; not only is it an environmentally friendly way to carry out research, it leads to more rapid feedback to, and responses from, panel members. In addition, reminder e-mails can be sent out automatically, and there is no cost in terms of postage or printing. Furthermore, busy respondents seeing one page at a time is perceived as being easier to complete than a full printed questionnaire.[21] For the purposes of the present study international experts in clinical teaching will be identified and considered to be potential participants in the study.

\section{Participants}

A group of 15 cardiac nurses from the UK $(n=8)$, Canada $(n=3)$, Australia $(n=3)$, New Zealand $(\mathrm{n}=1)$ and 17 from Italy were selected by an international panel of advisers and accepted to participate on a voluntary basis. The characteristics of the participants who provided their demographic details are summarised in Table 1.

\section{Sample size, selection criteria and duration of study}

There are no formal criteria for determining either the number of people required for a Delphi study as this is a mixed methods approach, which has elements of both qualitative and quantitative research.[22] While as few as three participants have been used, the recommended minimum 
number of participants is eight.[22] Similarly, there are no formal criteria for selecting participants in a Delphi study other than that they should be recognised experts in the field of the study.[22] In the present study, we selected Italian and internationally recognised experts in cardiac nursing based on the recommendation of our expert advisory panel; the members of our advisory panel did not participate in the Delphi study. We used Italian experts as the study aimed to provide competencies for Italian nurses and we decided to include international experts to investigate whether there was congruence between national and international experts. We considered that this could lend greater credibility to the outcome of the study. Finally, there are no formal criteria for deciding how many rounds of a Delphi study should take place. Some studies have used the reduction of standard errors around mean consensus scores[23] and the recommendations for achieving consensus range from 50-80\%.[22] However, the decision of where to stop returning to experts remains arbitrary. Without exception, all the studies we used as background for the present study used three rounds. One factor which also helps to determine the number of rounds is the likelihood of diminishing returns whereby the number of participants responding between rounds declines. It is unreasonable to expect any research participants to commit to multiple rounds of any study; 'research fatigue' [24] is inevitable, and this is especially true of the kind of people required for participation in a Delphi study.

\section{Procedure}

For the present project we followed the method described in a recent study[25] and, specifically, used an e-Delphi method in three rounds, which were conducted between April 2016 and February 2018.

\section{Round 1}

For round 1, each participant was invited to propose a minimum of five competencies, which they considered should be included in a list of statements of common clinical procedures. To obviate an extensive list being presented to participants in round 2, a list of approximately 20 competencies 
was prepared by examining those obtained in round 1 and rationalising these based on their frequency. Some items were similar, or procedures overlapped, and this was used to rationalise the list.

\section{Round 2}

A prioritized list of 14 competencies from round 1 was sent to each participant. Each participant was requested to state how important, in terms of priority, each competency was on a ten-point scale. Scores 1-3 represented the region where participants considered the item was not a priority; 4-6 represent the region of equivocality; and 7-10 represent the region where it is considered that the item is a priority. Strict agreement was obtained if all rankings fell within one of these regions. Once analysed, items for which $70 \%$ of participants did not rate within the scale of 7-9 were removed. These results were then fed back to the experts, who remained anonymous from one another-for round 3.

\section{Round 3}

In round 3, participants ranked the competencies using the same ten-point scale but this time with knowledge of the group scores. Thus, participants reflected on their score and had the opportunity to change theirs depending on the group score whilst also maintaining anonymity from one another. In this round all the competencies presented were scored within the $7-10$ region by $70 \%$ of the respondents so all were retained.

\section{RESULTS}

\section{Round 1}

In round one, 32 respondents (17 Italian; 15 international), were asked to identify a group of at least five competencies they considered important for nurses working in cardiac care to possess. Each respondent provided between five to ten competencies, which in the end were summarized to 
generate a list of 14 competencies (Table 2).

The most frequently mentioned competencies, both by international and Italian cardiac nurses were: 'ECG skills'; 'Health promotion'; 'Taking patient history and physical examination'; and 'Knowledge about cardiac pharmacology, interventions and heart diseases'. Some differences were observed in the number of times each competence was mentioned by international and Italian cardiac nurses were related to: 'Leadership skills (international $=1$; Italian $=10$ ); 'Healthcare process' (international $=0$; Italian $=7$ ); 'Organizational skills (international $=0$; Italian $=7$ ); and 'Advanced education and training' (international $=13$; Italian $=0$ ). Two competencies that were least mentioned by both international and Italian nurses were: 'continuing professional development' (international $=1$; Italian $=0$ ) and EBP / Reflective practice (international $=1$; Italian $=0)$.

\section{Round 2}

From this list, a prioritised list of competencies was generated in Round 2; 29 participants responded (12 international; 17 Italian) and the outcome is shown in Table 3. Very similar mean scores were obtained for 'Knowing how to assess and deal with signs and symptoms' (international =9.6; Italian =9.7); 'Knowledge about cardiac pharmacology, cardiac interventions, anatomy \& pathology of the heart' (international $=9.0$; Italian $=9.3$ ); ECG Skills (international $=9.2$; Italian $=$ 9.0); 'Taking Patient history and physical examination' (international $=9.0$; Italian $=9.2$ ); 'Communication Skills' (international = 9.0; Italian = 8.8); and 'Heath care process' (international $=8.8 ;$ Italian $=8.7$ )

Instead, the most divergent mean scores between international and Italian experts were obtained for 'Evidence based practice' (international = 7.3; Italian = 9.1), 'Organizational skills' (international $=8.2 ;$ Italian $=6.5)$, 'Advanced education and training' (International 7.7; Italian 9.2) and Leadership skills (international 7.7; Italian 9.0).

\section{Round 3}


Table 4 shows the outcome of round 3, where the rankings of other experts were revealed, to which 26 participants responded (16 Italian; 10 international). At all stages, we compared the results from the Italian and the international respondents, and their prioritization of competencies was very congruent, therefore outcomes were merged to produce the final list.

When comparing the priority given by Italian and international respondents to each competency, there were some differences between the two groups for 'Knowledge about cardiac pharmacology, cardiac interventions, anatomy \& pathology of the heart' (international = 7.9; Italian = 9.3); 'Taking patient history and physical examination' (international $=8.0$; Italian $=9.1$ ), 'Advanced education and training' (international = 8.1; Italian = 9.2), and 'EBP' (international = 7.3; Italian $=8.8$ ).

\section{DISCUSSION}

We set out to identify a set of core competencies that meet international standards for postgraduate specialization courses for Italian cardiac nurses. To achieve our aim, we consulted experts within Italy and internationally. Remarkable congruence was attained between the Italian and international experts, so we decided to merge and not to differentiate these responses. The most highly rated standards were those related to immediate assessment and diagnosis of the patient. An accurate initial patient assessment enables more effective care planning. This is done by applying intervention algorithms in the event of acute diseases, such as myocardial infarction, but also for chronic diseases, such as heart failure, where specific pathophysiological and pharmacological aspects must be known in order to provide the best possible support to help patients and their carers manage the disease. Knowing the principal assessment scales, also in relation to habits and lifestyle, enables a multidimensional and multiprofessional assessment and, consequently, the grading of the patient's disease, enabling the necessary interventions in the short and in the long term to be planned[26] Also, communication skills and health promotion were highly rated. A cardiac event is 
an anxiety-provoking time for a patient, and cardiac nurses need to be able both to obtain information from a patient and to assure them about the future with sound advice on lifestyle changes they can make. The inclusion of instruments and techniques for therapeutic consultation that enable the identification of patients who are at medium-high risk in advanced courses for cardiac nurses, would enable better outcomes in terms of adherence to treatment.[27] The lower rated standards were related to more peripheral, yet still important aspects, of the cardiac nurse's role; for example, management and evidence-based practice.

Cardiac nurses need to be highly prepared for their role and are expected to demonstrate a high degree of autonomy in practice and to manage patients without, necessarily, recourse to their medical colleagues and show leadership to their other non-specialist nursing colleagues. In the Italian context, the need for these standards arose because no such specific standards exist in Italy. This study highlights how the skills required by cardiac nurses are very advanced and specific. Officially recognized specialization courses for cardiac nurses are available in many European countries. Instead in Italy, cardiac nurses develop their specialist skills mainly during their clinical practice, by learning in the field, with the help of more experienced colleagues.[13]

The availability of standards of reference (or benchmarks) allows healthcare organizations to place nurses in cardiology services/settings, following a specific period of coaching or supervision, support and guidance by a specially trained nurse, with specific learning objectives that are in line with European standards. Nurses play an important role in the education and management of patients with a variety of cardiac conditions such as heart failure which, being chronic disease conditions, tend to get worse, often requiring the implantation of devices and remote telemetry, which require nurses to have advanced knowledge and skills.[28]

In Italy, there is no specialist training in cardiac nursing recognized at university level (e.g. no post-graduate courses in cardiac nursing). However, ACNAP offers its international audience the opportunity to attend webinars on clinical aspects and incentives to participate in educational 
conferences, as well as the provision of guidelines for cardiovascular nursing in many languages. Therefore, in countries where there are no specialist courses in cardiac nursing, ACNAP can help address this gap through its various learning resources and materials based on international standards. In centres where there is a greater degree of professionalism, for example, such as adequate staffing levels, degree-level preparation, length of service and years of experience in a specific clinical branch, there is a positive impact on the most important outcomes, such as mortality or readmission rate. [7]

\section{European standards}

The competencies identified in this study are congruent with those described in the core curriculum of the Heart Failure Association of the European Society of Cardiology, where knowledge about cardiac physiology, cardiac pathophysiology, health promotion and pharmacology are included in the fundamentals of cardiovascular pathophysiology.[29] According to European standards, the correct identification and recording of heart rate and signs and symptoms, and a precise collection of the patient's clinical history, is not only fundamental but a mandatory requirement for the correct management of the patient.[30] Communication skills play a key role in facilitating adherence to treatment and involvement of patients and their families in their care.

It should be acknowledged that the list of competencies is a disparate range of specific clinical skills (e.g. ECG interpretation), very broad and generic skills (e.g. communication), and relatively vague and all-encompassing attributes (e.g. advanced education). There is also substantial overlap, for example, similarities between assessing signs and symptoms and taking a patient history. It is also evident that some aspects of cardiac nursing care are missing such as assessment of quality of life, including the patient's social, relational, emotional and sexual well-being.[31]

\section{The way ahead}

To implement the standards in cardiac nursing, it would be useful to have a uniform postgraduate educational curricula and provide, for instance, self-assessment tools and online courses on specific 
topics (e.g. heart failure, acute myocardial infarction, interventional cardiology) similar to the European Society of Cardiology. In relation to this, there are various organizations that offer specialized training for cardiac nurses, with seminars and online lessons, which facilitate the acquisition of new knowledge and specialized competencies, and at the same time offer the opportunity, through various projects, to be mentored by tutors and obtain grants.[32,33] However, it should be noted that the language barrier often discourages nurses who are not proficient in English to understand, fully, online courses and resources, which are mostly in English.

The United Kingdom Nursing \& Midwifery Council declared that Registered Nurses play a vital role in providing, leading and coordinating care that is compassionate, evidence-based, and person-centred. They are accountable for their own actions and must be able to work autonomously, or as an equal partner with a range of other professionals, and in interdisciplinary teams. To respond to the impact and demands of professional nursing practice, they must be emotionally intelligent and resilient individuals, who are able to manage their own personal health and wellbeing and know when and how to access support.[34]

Another important aspect is multidisciplinary team working, where physicians and nurses collaborate, and together assess and plan care for their patients, to favour adherence to treatment and care.[35] An integrated patient care plan enables better patient management and outcomes.[29]

\section{Limitations}

An inherent limitation of the Delphi technique is the use of a non-random sample with regard to the members of the panel of experts.[21] The experts were selected for a specific purpose, and not randomly, therefore the representative nature of the sample cannot be assured. In addition, some experts that took part in our study might have known one another and could have exchanged their views and influenced their responses to the e-Delphi. Another limitation could have been the long duration of the study, almost two years, because of the difficulty getting feedback by some experts who were often very busy, but we preferred to grant more time to minimize dropout. 


\section{Conclusion}

This study provides a foundation for the development of postgraduate educational programmes for specialist cardiac nurses that are congruent with international standards. The standards of reference could also guide Italian academics in designing postgraduate advanced education courses that reflect a new vision of care, which does not only limit itself to clinical aspects but also takes into account how cardiovascular diseases impact on the population in terms of, for example, economic and social disparities.

Having a list of core competencies for cardiac nurses enables planning for personalized care and fostering new pathways that improve patient outcomes and experience. This also contributes to the drafting of job descriptions and the establishment of new forms of service organisation and delivery, such as nurse-led heart failure clinics.[36]

\section{IMPLICATIONS FOR PRACTICE}

- Identifying and mapping cardiac nurses' competencies enables the design of more advanced educational programs and identify gaps.

- Core competencies can be used as a benchmark for cardiac nurses.

- Such educational programs are likely to contribute to improved patient outcomes.

\section{ACKNOWLEDGEMENTS}

We thank our international (Felicity Astin, Mark Hayter, Kathryn King-Shier, Geraldine Lee, and Hugh McKenna) and Italian (Beatrice Magno and Gian Battista Danzi) advisors who selected the International and Italian expert panels and supported this study. We also thank the expert cardiac nurses who generously responded: Benedetta Arena (Italy); Sabrina Barro (Italy); Paolo Bottoni (Italy); Lorenzo Ciarma (Italy); Matteo Chiarabelli (Italy); Louise Clayton (UK); Antonella Corona (Italy); Sara Covi (Italy); Cristina Danza (Italy); Julia Decourcey (UK); Maurizio Di Renzo (Italy); Marco Facchini (Italy); Ting Fang Feng (UK); Francesco Germinal (Italy); Jane Hannah (New Zealand); Kelly Hanvey (Australia); Ian Jones (UK); Heather Leblanc (Canada); Catherine 
McIntyre (Canada); Tania Massey (UK); Rosa Miccoli (Italy); Fabio Negrello (Italy); Nunzio Panzera (Italy); Ivana Pastorino (Italy); Simonetta Predolini (Italy); Deborah Wright (Australia); Armanda Zerbini (Italy)

\section{Declaration of Conflicting Interests}

The Authors declare that there is no conflict of interest.

\section{Funding}

No funding was obtained for this study.

\section{REFERENCES}

1. Nakamura N, Koga $\mathrm{T}$ and Iseki H. A meta-analysis of remote patient monitoring for chronic heart failure patients. J Telemed Telecare 2014; 20(1): 11-17. DOI:10.1177/1357633X13517352

2. Engelen MM, van Dulmen S, Nijhuis-van der Sanden MW et al. Self-management support in cardiovascular consultations by advanced practice nurses trained in motivational interviewing: an observational study. Patient Educ Couns 2020; 103(1): 159-164. .DOI:10.1016/j.pec.2019.07.018

3. Kjellström B, Rydén L, Klinge B, et al. Periodontal disease-important to consider in cardiovascular disease prevention. Expert Rev Cardiovasc Ther 2016; 14(9): 987-989. DOI:10.1080/14779072.2016.1202112

4. Epstein RM and Hundert EM. Defining and assessing professional competence JAMA 2002; 287(2): 226-235. DOI:10.1001/jama.287.2.226

5. Watson R, Stimpson A, Topping A, Porock D. Clinical competence assessment in nursing: a systematic review of the literature. J Adv Nurs 2002; 39(5): 421-431. DOI: 10.1046/j.13652648.2002.02307.x 
6. Riley JP, Astin F, Crespo-Leiro MG, et al. Heart Failure Association of the European Society of Cardiology heart failure nurse curriculum. Eur $J$ Heart Fail 2016; 18(7): 736-743. DOI:10.1002/ejhf.56

7. Aiken LH, Sloane DM, Bruyneel L, et al. Nurse staffing and education and hospital mortality in nine European countries: a retrospective observational study. Lancet 2014; 383(9931): 18241830. DOI:10.1016/S0140-6736(13)62631-8

8. Astin F, Carroll DL, Ruppar T, et al. A core curriculum for the continuing professional development of nurses: developed by the Education Committee on behalf of the Council on Cardiovascular Nursing and Allied Professions of the ESC. Eur J Cardiovasc Nurs 2015; 14(3): 190-197. DOI: $10.1177 / 1474515115572048$

9. Hinterbuchner L, Coelho S, Esteves R, et al. A cardiac catheterisation laboratory core curriculum for the continuing professional development of nurses and allied health professions: developed by the Education working group of the Nurses and Allied Professions Committee for the European Association of Percutaneous Cardiovascular Interventions (EAPCI) 2016. EuroIntervention 2016; 12(16): 2028-2030. doi: 10.4244/EIJ-D-16-00374.

10. Ponikowski P, Voors AA, Anker SD, et al. 2016 ESC Guidelines for the diagnosis and treatment of acute and chronic heart failure: The Task Force for the diagnosis and treatment of acute and chronic heart failure of the European Society of Cardiology (ESC). Developed with the special contribution of the Heart Failure Association (HFA) of the ESC. Eur Heart J 2016; 37(27): 2129-2200. DOI: 10.1093/eurheartj/ehw128

11. White K, Macfarlane H, Hoffmann B, et al. Consensus statement of standards for interventional cardiovascular nursing practice. Heart Lung Circ 2018; 27(5): 535-551. DOI:10.1016/j.hlc.2017.10.022

12. Barisone M, Bagnasco A, Timmins F, et al. Approaches to nurse education and competence development in remote telemonitoring of heart failure patients with implanted heart devices in 
Italy: a cause for concern. Eur $J$ Cardiovasc Nurs 2018; 17(5): 338-389. DOI:10.1177/1474515117742132

13. Hsu C-C, Sandford BA. The Delphi technique: making sense of consensus. Pract Assess Res Eval 2007; 12(10): 1-8.

14. Dalkey N, Helmer O. An experimental application of the Delphi method to the use of experts. Manage Sci 1963; 9(3): 458-467. DOI:10.1287/mnsc.9.3.458

15. Better Evaluation. Sharing information to improve evaluation, http://www.betterevaluation.org/evaluation-options/delphitechnique (2012, accessed 29 October 2020)

16. McKenna HP. The Delphi technique: a worthwhile approach for nursing? J Adv Nurs 1994; 19(6): 1221-1225. DOI:10.1111/j.1365-2648.1994.tb01207.x

17. Chang AM, Gardner GE, Duffield C, et al. A Delphi study to validate an Advanced Practice Nursing tool. J Adv Nurs 2010; 66(10): 2320-2330. DOI:10.1111/j.1365-2648.2010.05367.x

18. Helms C, Gardner A, McInnes E. The use of advanced web-based survey design in Delphi research. J Adv Nurs 2017; 73(12): 3168-3177. DOI: 10.1111/jan.13381

19. Knighting K, O’Brien MR, Roe B, et al. Gaining consensus on family carer needs when caring for someone dying at home to develop the Carers' Alert Thermometer (CAT): a modified Delphi study. J Adv Nurs 2016; 72(1): 227-239. DOI:10.1111/jan.12752.

20. Taylor RM, Feltbower RG, Aslam N, et al. Modified international e-Delphi survey to define healthcare professional competencies for working with teenagers and young adults with cancer. BMJ Open, 2016; 6: e011361. DOI:10.1136/bmjopen-2016-011361

21. Keeney S, Hasson F, McKenna H. The Delphi technique in nursing and health research. Oxford: Wiley, 2010.

22. Ogbeifun E, Agwa-Ejon J, Mbohwa C, et al.. The Delphi technique: a credible research methodology. Proceedings of the 2016 International Conference on Industrial Engineering of Operations Management. Kuala Lumpur: IEOM. 8-10 March. 2016, pp. 2004-2009. 
23. Greatorex J, Dexter T. An accessible analytical approach for investigating what happens between the rounds of a Delphi study. J Adv Nurs 2000; 32(4): 1016-1024. DOI:10.1046/j.13652648.2000.t01-1-01569.x

24. Clark T. "We're over-researched here!": exploring accounts of research fatigue within qualitative research engagements. Sociology 2008; 42(5): 953-970. DOI:10.1177/0038038508094573

25. Meshkat B, Cowman C, Gethin G, et al. Using an e-Delphi technique in achieving consensus across disciplines for developing best practice in day surgery in Ireland. J Hosp Admin 2014; 3(4): 1-8. DOI: 10.5430/jha.v3n4p1

26. Mansoor SM, Krass I, Asiani P. Multiprofessional interventions to improve patient adherence to cardiovascular medications. J Cardiovasc Pharmacol Ther 2013; 18(1): 19-30. DOI: $10.1177 / 1074248412442001$

27. Lee WL, Abdullah KL, Bulgiba AM, et al. Prevalence and predictors of patient adherence to health recommendations after acute coronary syndrome: Data for targeted interventions? Eur J Cardiovasc Nurs 2013; 12(6): 512-520. DOI: 10.1177/1474515112470056

28. Bhimaraj A. Remote monitoring of heart failure patients. Methodist Debakey Cardiovasc $J$ 2013; 9(1): 26-31.

29. McDonagh TA, Gardner RS, Lainscak M, et al. Heart Failure Association of the European Society of Cardiology specialist heart failure curriculum. Eur J Heart Fail 2014; 16(2): 151162. DOI: $10.1002 /$ ejhf.41.

30. Riley JP, Astin F, Crespo-Leiro MG, et al. Heart Failure Association of the European Society of Cardiology heart failure nurse curriculum. Eur $J$ Heart Fail 2016; 18(7): 736-743. DOI:10.1002/ejhf.568

31. Thompson DR, Ski CF, Garside J, et al. A review of health-related quality of life patientreported outcome measures in cardiovascular nursing. Eur J Cardiovasc Nurs 2016;15(2): 114125. DOI: $10.1177 / 1474515116637980$ 
32. European Society of Cardiology. Association of Cardiovascular Nursing and Allied Professions, https://www.escardio.org/Sub-specialty-communities/Association-of-Cardiovascular-Nursing\&-Allied-Professions (Accessed 29 October 2020)

33. The CORE Project, https://www.corehearteducation.com (Accessed 29 October 2020)

34. NMC, Your future nurse. What our new standards for the future mean for you, https://www.nmc.org.uk/globalassets/sitedocuments/education-standards/your-future-nurse.pdf (Accessed 29 October 2020)

35. Blakeney EA, Lavallee DC, Baik D, et al.. Purposeful interprofessional team intervention improves relational coordination among advanced heart failure care teams. $J$ Interprof Care, 2019; 33(5): 481-489. DOI:10.1080/13561820.2018.1560248

36. Liljeroos M, Stromberg A. Introducing nurse-led heart failure clinics in Swedish primary care settings. Eur J Heart Fail 2019;21(1):103-109. DOI:10.1002/ejhf.1329 
Table 1. The characteristics of the cardiac nurses that responded to the e-Delphi survey.

\begin{tabular}{|c|c|c|}
\hline $\begin{array}{l}\text { Total Number of Experts who responded to } \\
\text { all of the } 3 \text { Rounds }\end{array}$ & $\mathrm{N}=26$ & \\
\hline $\begin{array}{l}\text { Total number of experts who provided their } \\
\text { sociodemographic data }\end{array}$ & $\mathrm{N}=17$ & \\
\hline Gender & $\begin{array}{l}\text { Females }=14 \\
\text { Males }=3\end{array}$ & \\
\hline Mean age & 45.8 years & \\
\hline Mean number of years since qualified as $\mathrm{RN}$ & 22.3 years & \\
\hline Mean number of years in cardiac nursing & 17.9 years & \\
\hline Mean number of years in current position & 8.6 years & \\
\hline Country & $\begin{array}{l}\text { Italy } \\
\text { United Kingdom } \\
\text { Australia } \\
\text { Canada } \\
\text { New Zealand }\end{array}$ & $\begin{array}{l}\mathbf{N} \\
7 \\
5 \\
2 \\
2 \\
1\end{array}$ \\
\hline Highest Educational Qualification & $\begin{array}{l}\text { Master's Degree in Nursing } \\
\text { Post-graduate certificate/diploma } \\
\text { Graduate Degree } \\
\text { PhD }\end{array}$ & $\begin{array}{l}8 \\
6 \\
2 \\
1\end{array}$ \\
\hline Current job position & $\begin{array}{l}\text { Heart Failure Nurse Specialists } \\
\text { Ward Managers/Coordinators } \\
\text { Academics } \\
\text { Cardiac Intensive Care Nurses } \\
\text { Heart Failure Nurse Consultants } \\
\text { Cardiac Clinical Nurses } \\
\text { Advanced Nurse Practitioners } \\
\text { Deputy Head of Cardiovascular Nursing }\end{array}$ & $\begin{array}{l}3 \\
3 \\
3 \\
2 \\
2 \\
2 \\
1 \\
1\end{array}$ \\
\hline
\end{tabular}


Table 2. Core competencies collected at the end of Round 1. A merged list of the responses given by 15 international experts and 17 Italian experts of cardiac nursing.

\begin{tabular}{|c|c|c|c|c|}
\hline CORE COMPETENCE & $\begin{array}{c}\text { INT'L } \\
\text { (Frequency) }\end{array}$ & $\begin{array}{c}\text { ITALY } \\
\text { (Frequency) }\end{array}$ & TOTALS & COMMENTS \\
\hline $\begin{array}{l}\text { 1. ECG Skills } \\
\text { (Recognizing significant ECG alterations) }\end{array}$ & 12 & 14 & 26 & $\begin{array}{l}\text { Double counted one } \\
\text { here as part of } \\
\text { physical } \\
\text { examination }\end{array}$ \\
\hline $\begin{array}{l}\text { 2. Health promotion } \\
\text { (Educate, inform, communicate with patients } \\
\text { and their family or caregiver) }\end{array}$ & 10 & 13 & 23 & \\
\hline $\begin{array}{l}\text { 3. Knowledge about cardiac pharmacology, } \\
\text { cardiac interventions, anatomy \& } \\
\text { pathology of the heart }\end{array}$ & 11 & 7 & 18 & \\
\hline $\begin{array}{l}\text { 4. Knowing how to assess and deal with } \\
\text { signs and symptoms } \\
\text { (Chest pain management }+ \text { management of } \\
\text { heart failure+ managing cardiac surgical } \\
\text { patients) }\end{array}$ & 5 & 12 & 17 & \\
\hline $\begin{array}{l}\text { 5. Communication skills } \\
\text { (Relational-communication skills) }\end{array}$ & 4 & 12 & 16 & \\
\hline $\begin{array}{l}\text { 6. Knowing how to use cardiology } \\
\text { equipment and specialized knowledge of } \\
\text { monitoring systems } \\
\text { (hemodynamic monitoring + knowledge of } \\
\text { cardiac inserts - stents/pacemakers) }\end{array}$ & 5 & 11 & 16 & \\
\hline $\begin{array}{l}\text { 7.Taking patient history and physical } \\
\text { examination } \\
\text { (Admitting cardiac patient to ward. } \\
\text { Measuring vital signs, correct use of nursing } \\
\text { documentation and assessment scales) }\end{array}$ & 9 & 7 & 16 & \\
\hline 8. Advanced education and training & 13 & 0 & 13 & $\begin{array}{l}\text { This includes } \\
\text { ALCS, critical care, } \\
\text { A\&E training }\end{array}$ \\
\hline $\begin{array}{l}\text { 9. Leadership skills } \\
\text { (decision making and problem solving) }\end{array}$ & 1 & 10 & 11 & \\
\hline 10. Critical appraisal skills & 2 & 8 & 10 & \\
\hline 11. Healthcare process & 0 & 7 & 7 & \\
\hline $\begin{array}{l}\text { 12. Organizational skills } \\
\text { (managerial and relations linked to manager } \\
\text { role) }\end{array}$ & 0 & 7 & 7 & \\
\hline 13. Continuing professional development & 1 & 0 & 1 & \\
\hline 14. EBP (reflective practice) & 1 & 0 & 1 & \\
\hline Oxygen therapy & 2 & & & Italian experts \\
\hline Discharge procedures & 1 & & & suggested to \\
\hline Palliative care & 2 & & & include these in \\
\hline Blood sampling & 1 & & & “Healthcare \\
\hline Psychological care & 2 & & & $\begin{array}{l}\text { process" in the next } \\
\text { Round. }\end{array}$ \\
\hline
\end{tabular}


Table 3. Round 2 results of e-Delphi: score sheet with merged list of core cardiac nursing competencies and respective mean scores provided by 12 international experts and 17 Italian experts, ordered according to the total mean priority score.

\begin{tabular}{|c|c|c|c|}
\hline CORE COMPETENCIES & $\begin{array}{l}\text { MEAN } \\
\text { SCORES } \\
\text { INT'L }\end{array}$ & $\begin{array}{l}\text { MEAN } \\
\text { SCORES } \\
\text { ITALY }\end{array}$ & $\begin{array}{l}\text { TOTAL } \\
\text { MEAN } \\
\text { SCORES }\end{array}$ \\
\hline $\begin{array}{l}\text { 1. Knowing how to assess and deal with signs and symptoms } \\
\text { (Chest pain management + management of heart failure+ managing } \\
\text { cardiac surgical patients) }\end{array}$ & 9.6 & 9.7 & 9.65 \\
\hline $\begin{array}{l}\text { 2. Knowledge about cardiac pharmacology, cardiac interventions, } \\
\text { anatomy \& pathology of the heart }\end{array}$ & 9.0 & 9.3 & 9.15 \\
\hline $\begin{array}{l}\text { 3. ECG Skills } \\
\text { (Recognizing significant ECG alterations) }\end{array}$ & 9.0 & 9.2 & 9.10 \\
\hline $\begin{array}{l}\text { 4. Health promotion } \\
\text { (Educate, inform, communicate with patients and their family or caregiver) }\end{array}$ & 9.3 & 8.9 & 9.10 \\
\hline $\begin{array}{l}\text { 5. Taking patient history and physical examination } \\
\text { (Admitting cardiac patient to ward. Measuring vital signs, correct use of } \\
\text { nursing documentation and assessment scales) }\end{array}$ & 9.0 & 9.2 & 9.10 \\
\hline $\begin{array}{l}\text { 6. Communication skills } \\
\text { (Relational-communication skills) }\end{array}$ & 9.0 & 8.8 & 8.90 \\
\hline $\begin{array}{l}\text { 7. Health care process } \\
\text { (Oxygen therapy, Discharge procedures, Palliative care, Blood sampling, } \\
\text { Psychological care) }\end{array}$ & 8.8 & 8.7 & 8.75 \\
\hline 8. Continuing professional development & 8.2 & 8.8 & 8.50 \\
\hline 9. Advanced education and training & 7.7 & 9.2 & 8.45 \\
\hline $\begin{array}{l}\text { 10. Know about monitoring system and cardiology equipment } \\
\text { (Hemodynamic monitoring + knowledge of cardiac inserts stents / } \\
\text { pacemakers) }\end{array}$ & 7.9 & 8.9 & 8.40 \\
\hline $\begin{array}{l}\text { 11. Leadership skills } \\
\text { (Decision making and problem solving) }\end{array}$ & 7.7 & 9.0 & 8.35 \\
\hline 12. Critical appraisal skills & 7.5 & 9.1 & 8.30 \\
\hline $\begin{array}{l}\text { 13. EBP } \\
\text { (reflective practice) }\end{array}$ & 7.3 & 9.1 & 8.20 \\
\hline $\begin{array}{l}\text { 14. Organizational skills } \\
\text { (managerial and relations linked to manager role) }\end{array}$ & 6.5 & 8.2 & 7.35 \\
\hline
\end{tabular}


Table 4. Results of Round 3 of the e-Delphi study: Core cardiac nursing competencies and total mean scores attributed by 10 international and 17 Italian experts after revealing the rankings provided by other experts in Round 2.

\begin{tabular}{|c|c|c|c|}
\hline COMPETENCIES & $\begin{array}{l}\text { MEAN } \\
\text { SCORES } \\
\text { INT'L }\end{array}$ & $\begin{array}{l}\text { MEAN } \\
\text { SCORES } \\
\text { ITALY }\end{array}$ & $\begin{array}{l}\text { TOTAL } \\
\text { MEAN } \\
\text { SCORES }\end{array}$ \\
\hline $\begin{array}{l}\text { 1. Knowing how to assess and deal with signs and symptoms } \\
\text { (Chest pain management + management of heart failure+ managing cardiac } \\
\text { surgical patients) }\end{array}$ & 9.5 & 9.8 & 9.65 \\
\hline $\begin{array}{l}\text { 2. ECG Skills } \\
\text { (Recognizing significant ECG alterations) }\end{array}$ & 9.8 & 9.5 & 9.65 \\
\hline $\begin{array}{l}\text { 3. Knowledge about cardiac pharmacology, cardiac interventions, } \\
\text { anatomy \& pathology of the heart }\end{array}$ & 7.9 & 9.3 & 8.65 \\
\hline $\begin{array}{l}\text { 4. Health promotion } \\
\text { (Educate, inform, communicate with patients and their family or caregiver) }\end{array}$ & 9.8 & 9.2 & 9.50 \\
\hline $\begin{array}{l}\text { 5. Taking patient history and physical examination } \\
\text { (Admitting cardiac patient to ward. Measuring vital signs, correct use of } \\
\text { nursing documentation and assessment scales) }\end{array}$ & 8.0 & 9.1 & 8.50 \\
\hline $\begin{array}{l}\text { 6. Communication skills } \\
\text { (Relational-communication skills) }\end{array}$ & 9.3 & 8.8 & 9.05 \\
\hline $\begin{array}{l}\text { 7. Health care process } \\
\text { (Oxygen therapy, Discharge procedures, Palliative care, Blood sampling, } \\
\text { Psychological care) }\end{array}$ & 8.1 & 8.8 & 8.54 \\
\hline 8. Advanced education and training & 8.1 & 9.2 & 8.65 \\
\hline $\begin{array}{l}\text { 9. Know about monitoring system and cardiology equipment } \\
\text { (Hemodynamic monitoring + knowledge of cardiac inserts -stents / } \\
\text { pacemakers) }\end{array}$ & 9.2 & 9.3 & 9.25 \\
\hline $\begin{array}{l}\text { 10. Leadership skills } \\
\text { (Decision making and problem solving) }\end{array}$ & 8.9 & 9.2 & 9.05 \\
\hline 11. Critical appraisal skills & 8.6 & 9.0 & 8.80 \\
\hline 12. Continuing professional development & 8.8 & 8.8 & 8.80 \\
\hline $\begin{array}{l}\text { 13. EBP } \\
\text { (reflective practice) }\end{array}$ & 7.3 & 8.8 & 8.05 \\
\hline 14. Organizational skills (managerial and relations linked to manager role) & 7.9 & 8.5 & 8.20 \\
\hline
\end{tabular}

